\title{
PEMANFAATAN SERBUK HALUS TRAS ASAL KULON PROGO SEBAGAI PENGGANTI SEBAGIAN SEMEN PADA MORTAR
}

\author{
Oleh : Nurokhman ${ }^{1}$ \\ E-mail: nurokhman.jogja@gmail.com
}

\begin{abstract}
Abstrak: Salah satu pertimbangan ekonomi dalam pembuatan mortar adalah jumlah semen. Adanya potensi bahan lokal tras di Kulon Progo Yogyakarta menjadi pemikiran dalam upaya menggali potensi sumber alam lokal untuk membuat mortar yang murah tetapi tidak mengurangi kualitas. Tujuan dari penelitian untuk mengetahui pengaruh penambahan tras dalam campuran mortar sebagai bahan pengganti sebagain semen terhadap kekuatan mortar.

Penelitian ini dilakukan di Laboratorium Bahan PAU Universitas Gadjah Mada. Agregat yang digunakan adalah pasir dari Kali Krasak, bahan tambah yang digunakan adalah tras dengan prosentase penambahan 0\%, 10\%, 20\%, 30\% terhadap pasir dan fas 0.60 . Pengujian yang dilakukan adalah kuat tekan dengan menggunakan cetakan mortar dengan ukuran $50 \times 50 \times 50 \mathrm{~mm}$, kuat lentur dengan cetakan balok dengan ukuran $50 \times 50 \times 300 \mathrm{~mm}$, kuat tarik dengan cetakan berbentuk angka delapan dengan ukuran p: $75 \mathrm{~mm}$ l: $50 \mathrm{~mm}$ dan lebar tengan $25 \mathrm{~mm}$ dan untuk

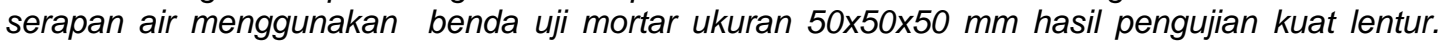
Pengujian kuat tekan pada umur 14, 21 dan 28 hari dan kuat tarik, lentur dan daya serap air pada umur 28 hari

Dari hasil penelitian diperoleh, bahwa dengan adanya penambahan bahan tambah tras pada mortar tidak dapat meningkatkan kuat tekan dan kuat lentur dan kuat tarik mortar. Daya serap air pada mortar meningkat antara 8.11 - -13,85\%. Pada umur 28 hari untuk penambahan tras 0\%, $10 \%, 20 \%$, 30\% masing-masing kuat tekannya adalah $151.577 \mathrm{~kg} / \mathrm{cm}^{2}, 108.426 \mathrm{~kg} / \mathrm{cm}^{2}, 110.187$ $\mathrm{kg} / \mathrm{cm}^{2}, 96.939 \mathrm{~kg} / \mathrm{cm}^{2}$ dan kuat lentur $12.279 \mathrm{~kg} / \mathrm{cm}^{2}, 8.795 \mathrm{~kg} / \mathrm{cm}^{2}, 11.678 \mathrm{~kg} / \mathrm{cm}^{2}, 9.615 \mathrm{~kg} / \mathrm{cm}^{2}$ dan kuat tarik $15.864 \mathrm{~kg} / \mathrm{cm}^{2}, 7.547 \mathrm{~kg} / \mathrm{cm}^{2}, 7.620 \mathrm{~kg} / \mathrm{cm}^{2}, 5.310 \mathrm{~kg} / \mathrm{cm}^{2}$.
\end{abstract}

Kata kunci : daya serap air, mortar, mortar, kuat tekan, kuat lentur, Tras

\section{PENDAHULUAN}

Adanya kebijakan pemerintah pada pemberdayaan sumber daya lokal baik dalam sektor fisik maupun non fisik telah membangkitkan pemerintah daerah untuk melakukan berbagai peningkatan kinerja produksi termasuk bahan galian dan perumahan. Bahan galian sebagai bahan baku konstruksi hingga saat ini masih terus dilakukan pengembangan dan penelitian untuk mengetahui kemungkinan positif mempunyai nilai mutu dan ekonomi yang dapat diterima masyarakat umum.

Pada saat ini perkembangan dalam bidang konstruksi mengalami kemajuan yang sangat pesat. Secara kontinyu dilakukan berbagai penelitian teknologi beton untuk meningkatkan kualitas beton. Penelitian-penelitian tersebut mencakup cara pemilihan bahan yang lebih baik dan komposisi campuran tertentu, sehingga didapatkan mutu standar yang direncanakan. Oleh karena itu perlu dipilih bahan-bahan tambahan tertentu yang sesuai, untuk menghasilkan beton dengan kekuatan dan tujuan tertentu yang diinginkan serta biaya yang seekonomis mungkin. Dan dengan didukung kondisi dan letak geografis wilayah Indonesia yang banyak menyimpan sumber daya alam, maka dimungkinkan memanfaatkan salah satu bahan galian yang berupa tras sebagai bahan susun beton dan mortar.

Penelitian yang dilakukan ini merupakan penelitian lanjutan dari beberapa penelitian tentang mortar sebelumnya. Sutriman dan Nurokhman, 2001, telah meneliti pengaruh pengguanan pasir pantai parangtritis

1) adalah staf pengajar Program Studi Teknik Sipil Universitas Cokroaminoto Yogyakarta

44 Pemanfaatan Serbuk Halus Tras Asal Kulon Progo Sebagai Pengganti Sebagian Semen Pada Mortar (Nurokhman) 
Yogyakarta terhadap kuat tekan dan daya derap air conblock. Sutikno Hariyoso, 2002, melakukan penelitian tentang pengaruh penambahan abu sekam padi terhadap kuat tekan dan daya serap air pada conblock dengan pasir

parangtritis. Nurokhman, 1999, penelitian tentang komparasi kuat tekan mortar dengan pasir asal Sungai Gelis, Sungai Krasak dan Sungai Progo. Penelitian Suyadi dan Nurokhman, 2005, tentang pengaruh penggunaan tras untuk mortar semen pada counblok. sehingga nantinya akan diperoleh hasil penelitian lanjutan yang bervariasi.

Tras adalah batuan gunung api yang telah mengalami perubahan komposisi kimia yang disebabkan oleh pelapukan dan pengaruh kondisi air bawah tanah. Bahan galian ini berwarna putih kekuningan hingga putih kecoklatan, kompak dan padu dan agak sulit digali dengan alat sederhana. Pada saat ini belum dimanfaatkan secara optimal. (www. garut.go.id ). Dari hasil pengujian batu tras di Direktorat Vulkanologi No. Analisa 08/10/LK/1997 menunjukkan komposisis tras adalah $\mathrm{SiO}_{2} \quad 46,65 \%, \mathrm{Al}_{2} \mathrm{O}_{3} \quad 24,56 \%$, $\mathrm{Fe}_{2} \mathrm{O}_{3} 15,85 \%, \mathrm{MgO} 1,70 \%, \mathrm{CaO} 1,28 \%$.

Dengan perekonomian yang terpuruk saat ini mengakibatkan melambungnya hargaharga termasuk material yang digunakan dalam pembangunan fisik seperti semen, namun pembangunan harus tetap berjalan, sehingga muncul penelitian-penelitian mengenai batako yang meliputi cara pemilihan dan komposisi bahan yang lebih baik dan penambahan bahan tambah atau pengganti untuk memperbaiki dan menambah karakteristik batako guna memperoleh mutu batako sesuai dengan yang diharapkan. Denagan adanya bahan tambah atau pengganti berupa tras diharapkan bisa menambah kekuatan batako.

Permasalahan yang perlu dibahas dalam penelitian ini yaitu pertama adakah pengaruh penambahan tras terhadap kuat tekan, kuat lentur dan kuat tarik mortar. Kedua pada prosentase berapakah penambahan tras dapat mencapai kekuatan yang optimal.

Penelitian ini diharapkan bermanfaat bagi perkembangan masalah beton dan mortar dalam dunia keteknik sipilan, selain itu juga dengan penelitian ini diharapkan dapat diketahui pengaruh penggunaan tras pengganti pasir sebagai bahan pembuatan Batako.

Penelitian ini bertujuan untuk mengetahui kuat tekan, kuat tarik, kuat lentur dan daya serap air pada Batako sebagai dinding dengan penggunaan tras sebagai bahan tambah. Dengan benda uji berupa mortar semen dan bahan tambah berupa tras.

\section{TINJAUAN PUSTAKA}

\subsection{Mortar}

Mortar sering disebut dengan mortel/spesi adalah adukan yang terdiri dari pasir, bahan perekat dan air. Bahan perekat dapat berupa tanah liat kapur, semen portland, bila tanah liat yang dipakai sebagai perekat disebut mortar lumpur, bila yang dipakai kapur disebut mortar kapur, dan begitu pula bila yang dipakai semen portland sebagai perekat disebut $\mathrm{m}$ rtar semen, dan pasir sebagai bahan pengisi bahan yang direkatkan, (Tjokrodimuljo, 1996).

Penggunaan mortar dalam pekerjaan konstruksi antara lain sebagai berikut (singh and singh, 1979) :

Digunakan pada pekerjaan bangunan untuk merekatkan batu bata atau balok beton, Untuk memperoleh permuakaan batu bata atau blok beton yang rata dan mencegah ketidakrataan sambungan, Digunakan untuk memplester permukaan bangunan dan melindungi dari pengaruh cuaca dan memberi hasil akhir yang halus dan baik, Pada beton, mortar digunakan untuk mengikat agregat kasar.

Mortar yang digunakan untuk pekerjaan bangunan harus memiliki sifat-sifat sebagai berikut (Tjokrodimuljo, 1996) :

Mudah dikerjakan, Tahan lama, Murah, Melekat dengan baik pada beton dan sebagainya,Cepat kering atau mengeras, Tahan terhadap rembesan, Tidak timbul retak-retak setelah dipasang.

Pemanfaatan Serbuk Halus Tras Asal Kulon Progo Sebagai Pengganti Sebagian

Semen Pada Mortar (Nurokhman) 
Mortar semen tersusun dari semen, pasir dan air pada proporsi yang sesuai. Perbandingan volume semen dan pasir berkisar $1: 2$ sampai $1: 6$ atau lebih. Mortar ini lebih kuat dibanding dengan motar yang lain, oleh karena itu mortar semen sering digunakan untuk tembok, pilar kolom, atau bagian lain yang menahan beban. Karena mortar ini rapat air maka juga digunakan untuk bagian luar dan yang ada dalam tanah. Pencampuran mortar tidak dengan penggilingan seperti pada mortar kapur. Semen dan pasir dicampur dalam keadaan kering pada tempat yang rata dan rapat air. Kemudian sebagian air yang diperlukan dapat tercampur seluruhnya. Untuk pekerjaan besar dengan suplai mortar diperlukan secara terus-menerus dapat digunakan dengan mesin pengaduk

Proporsi mortar semen untuk berbagai tinjauan tertentu dapat dilihat di bawah ini (singh and singh, 1979)

1. Pekerjaan bangunan $1: 6$ sampai $1: 8$

2. Fondasi beton $1: 3$ sampai $1: 4$

3. Pekerjaan lengkungan $1: 3$

4. Penyambungan $1: 2$ sampai $1: 3$

5. Pekerjaan memplester $1: 3$ sampai $1: 4$

\subsection{Kekuatan Mortar}

Bila dilihat dari bahan susunnya, batako sama dengan mortar semen sehingga kekuatannya sama yaitu dipengaruhi oleh beberapa faktor. Secara umum faktor yang mempengaruhi kekuatan mortar dan beton antara lain (Tjokrodimuljo, 1996) faktor air semen, umur beton, jenis semen, dan sifat agregat.

Bahwa semakin rendah nilai faktor air semen semakin tinggi kuat tekan beton, namun kenyataannya pada suatu nialai faktor air semen tertentu semakin rendah pula, hal ini karena jika faktor air semen terlalu rendah adukannya sulit dipadatkan. Penetapan jumlah semen, faktor air semen dimaksudkan agar beton yang diperoleh tidak cepat rusak maka perlu ditetapkan jumlah semen minimum dan nilai faktor air semen .

Kuat tekan beton atau mortar bertambah sesuai dengan bertambahnya umur, kecepatan sangat dipengaruhi oleh beberapa faktor antara lain, faktor air semen dan suhu perawatan. Semakin tinggi air semen semakin lambat kenaikan kekuatan beton dan semakin tinggi suhu perawatannya semakin cepat kenaikan kekuatan beton.

Menurut PUBI, 1982 sesuai dengan tujuan pemakainnya, semen portland dibagi dalam 5 jenis. Jenis I untuk konstruksi pada umumnya, dimana untuk diminta persyaratan khusus seperti yang disyaratkan pada jenis-jenis lainnya. Jenis II untuk kostruksi umumnya terutama sekali disyaratkan agak tahan terhadap sulfat dan panas hidrasi yang sedang. Jenis III untuk konstruksi-konstruksi yang menuntut persyaratan kekuatan yang tinggi. Jenis IV untuk konstruksi-konstruksi yang menuntut panas hidrasi yang rendah. Jenis $\mathrm{V}$ untuk konstruksi-konstruksi yang menuntut persyaratan sangat tahan terhadap sulfat.

Jumlah kandungan semen berpengaruh terhadap kuat tekan beton Jika faktor air semen sama, (nilai slump berubah) dengan kandungan semen tertentu mempunyai kuat tekan tinggi. Pada jumlah semen yang terlalu sedikit berarti jumlah air juga sedikit sehingga adukan sulit dipadatkan sehingga kuat tekannya rendah. Namun jika jumlah semen berlebihan berarti jumlah air juga berlabihan sehingga mengandung banyak pori dan akibatnya kuat tekannya rendah. Hubungan kuat tekan beton dengan jumlah semen dapat dilihat pada 
Sifat agregat yang paling berpengaruh terhadap kekuatan adalah bentuk tekstur, dan ukuran maksimum agregat. Bentuk yang bersudut dan tekstur yang kasar akan memberikan kontribusi yang baik terhadap kekuatan. Semakin besar ukuran maksimum agregat yang dipakai akan berakibat semakin tinggi kekuatannya. Hal ini disebabkan karena pemakaian butir agregat besar, menyebabkan pasta semen yang sedikit, yang berarti pori-pori kapiler yang terbentuk juga sedikit.

\subsection{Batako}

Menurut PUBI ( 1982 ) Batako atau batu cetak tras-kapur adalah batu yang dibuat dengan mencetak dan memelihara suasana lembab, campuran tras, kapur dan air dengan atau bahan tambah lainnya.

Syarat syarat batako:

- Tampak permukaan batako harus mulus, sisi-sisinya tegak lurus satu sama lain, datar dan tepinya tidak mudah dirapikan dengan tangan.

- Sebelum dipakai pada bangunan, batako harus berumur minimal 1 bulan bila pemeliharaan tidak dilakukan dalam ruang pemeliharaan khusus pada waktu perbuatannya.

- Pada waktu dipasang pada bangunan, batako harus cukup kering, yaitu kadar airnya tidak lebih dari $15 \%$.

Tabel 1 Syarat fisik batako standard PUBI ( 1982 )

\begin{tabular}{|c|c|c|c|}
\hline \multirow{2}{*}{$\begin{array}{c}\text { Batako } \\
\text { berlubang }\end{array}$} & \multicolumn{2}{|c|}{$\begin{array}{c}\text { Kuat tekan bruto minimum } \\
\left(\mathrm{kg.f} / \mathrm{cm}^{2}\right)\end{array}$} & $\begin{array}{c}\text { Penyerapan air } \\
\text { maksimum } \% \\
\text { berat) }\end{array}$ \\
\cline { 2 - 3 } & Rata-rata & $\begin{array}{c}\text { Masing- } \\
\text { masing }\end{array}$ & \\
\hline A1 & 20 & 17 & - \\
\hline A2 & 35 & 30 & - \\
\hline B1 & 50 & 45 & 35 \\
\hline B2 & 70 & 65 & 23 \\
\hline
\end{tabular}

A1 dan A2 untuk dipakai dalam konstruksi yang tidak memikul beban, dimana A1 dipasang pada tempat yang terlindung dari cuaca luar dan diberi lapisan pelingdung dan A2 sama dengan A1 tetapi dapat tanpa lapisan pelindung. B1 dan B2 dapat dipakai dalam konstruksi yang memikul beban dimana B1 ditempat-tempat yang terlindung dari cuaca luar dan B 2 dapat ditempat yang tak terlindung dari cuaca.

\subsection{Tras}

Tras merupakan lapukan batu-batuan yang berasal dari gunung berapi yang banyak mengandung silika, yang dalam keadaan halus apabila dicampur dengan kapur dan air, setelah beberapa waktu dapat mengeras pada suhu kamar membentuk masa yang padat dan sukar larut dalam air.

Kenampakan dilapangan bahan galian tras ini menunjukan warna putih kecoklatan sampai abu-abu cerah, putih abu-abu, bersifat lunak, agak lepas, pasiran, porositasnya sangat baik, kadang-kadang masih dijumpai fragmen adesit sebanyak $10-30 \%$. Dalam penelitian ini tras berasal dari Sungai Kulon progo yang dihaluskan lolos saringan $2,4 \mathrm{~mm}$.

Adapun ketentuan mutu bahan galian tras berdasarkan sifat fisiknya tampak pada Tabel 2

Tabel 2 Mutu tras dan semen merah Indonesia berdasarkan sifat-sifat fisiknya. 


\begin{tabular}{|c|c|c|c|}
\hline \multirow{2}{*}{ Pokok yang dipersyaratkan } & \multicolumn{3}{|c|}{ Tingkat } \\
\hline & I & II & III \\
\hline $\begin{array}{l}\text {-Kadar air bebas dalam \% pada suhu } 110^{\circ} \mathrm{C} \\
\text {-Kehalusan : tras selurughnya lewat ayakan 2,5 mm, } \\
\text { sisa diatas ayakan } 0,21 \mathrm{~mm} \text { dalam } \% \\
\text {-Waktu pengikatan : dinyatakan dalam kelipatan } 24 \text { jam } \\
\text {-Keteguhan aduk, pada umur } 14 \text { hari dalam } \mathrm{kg} / \mathrm{cm}^{2} \\
\text {-Keteguhan tekan } \\
\text {-Keteguhan tarik }\end{array}$ & $\begin{array}{c}<6 \\
10 \\
1\end{array}$ & $\begin{array}{c}6-8 \\
10-30 \\
2 \\
100-75 \\
16-12\end{array}$ & $\begin{array}{l}8-10 \\
30-50 \\
\quad 3 \\
75-50 \\
12-8\end{array}$ \\
\hline
\end{tabular}

Sumber: Peraturan tras dan semen merah Indonesia, 1979

Sedangkan standar mutu bahan galian tras berdasarkan sifat kimianya tampak pada Tabel 3

Tabel 3 Mutu tras berdasarkan sifat kimianya

\begin{tabular}{|l|c|c|c|}
\hline \multicolumn{1}{|c|}{ Unsur } & \multicolumn{3}{c|}{ Tingkat } \\
\cline { 2 - 4 } & $\mathrm{N}$ & $\mathrm{F}$ & $\mathrm{C}$ \\
\hline $\mathrm{Si}_{2}+\mathrm{Al}_{2} \mathrm{O}_{3}+\mathrm{Fe}_{2} \mathrm{O}_{3}$, min (\%) & 70,0 & 70,0 & 70,0 \\
$\mathrm{SO}_{3}$,maks (\&) & 4,0 & 5,0 & 5,0 \\
Kadar air,maks (\&) & 3,0 & 3,0 & 3,0 \\
Hilang pijar,maks (\&) & 10,0 & 10,0 & 10,0 \\
Alkali sebagai Na2 O, maks (\%) & 1.5 & 1,5 & 1,5 \\
Poz. Activity dengan kapur pada umur 7 hari, min & 800,0 & 800,0 & $*$ \\
(psi) & & & \\
\hline
\end{tabular}

Sumber : Portland Pozzolan Cement (PPC), 1994

Ket : * tidak dipersyaratkan

\section{LANDASAN TEORI}

\subsection{Perencanaan Campuran}

Perencanaan campuran dimaksudkan agar yang didapatkan dari campuran itu dengan hasil yang sebaik-baiknya. Perencanaan campuran dalam pengujian ini menggunkan metode "Road Note No.4" dengan rumus sebagai berikut :

$$
\frac{\mathrm{S}}{\mathrm{Y}_{\mathrm{s}} \cdot \mathrm{Y}_{\mathrm{air}}}+\frac{\mathrm{P}_{\mathrm{psr}} \cdot \mathrm{S}}{\mathrm{Y}_{\mathrm{psr}} \cdot \mathrm{Y}_{\text {air }}}+\frac{\mathrm{A} \cdot \mathrm{S}}{\mathrm{Y}_{\text {air }}}+0,01 \cdot \mathrm{V}=1 \mathrm{~m}^{3}
$$

Dengan : $Y_{\mathrm{s}} \quad$ : Berat jenis semen, $\mathrm{Y}_{\mathrm{psr}} \quad$ : Berat jenis pasir, $\mathrm{Y}_{\mathrm{air}} \quad$ : Berat jenis air, $\mathrm{V} \quad$ : Prosentase udara dalam air, $\mathrm{S}$ : Berat semen untuk $1 \mathrm{~m}^{3}$ beton.

Perhitungan untuk menentukan banyaknya bahan susun adalah sebagai berikut: $1 \mathrm{~m}^{3}$ mortar $\quad=\mathrm{V}_{\mathrm{pc}}+\mathrm{V}_{\text {pasir }}+\mathrm{V}_{\text {air }}+\mathrm{V}_{\text {udara }}$

\subsection{Pengujian Mortar}

A. Pengujian kuat tekan

Pengujian untuk kuat tekan mortar berupa kubus kecil dengan ukuran sisinya $50 \mathrm{~mm} \times 50 \mathrm{~mm} \times 50 \mathrm{~mm}$ sketsa benda uji tampak pada Gambar 3.1 dan rumus untuk mencari kuat tekannya adalah sebagai berikut :

$$
f^{\prime} c=\frac{F}{A}
$$

Dengan : F'C $=$ Kuat tekan mortar $\left(\mathrm{kg} / \mathrm{cm}^{2}\right), \mathrm{F} \quad=$ Beban atau gaya $(\mathrm{kg}), \mathrm{A}=$ Luas penampang $\left(\mathrm{cm}^{2}\right)$

48 Pemanfaatan Serbuk Halus Tras Asal Kulon Progo Sebagai Pengganti Sebagian Semen Pada Mortar (Nurokhman) 

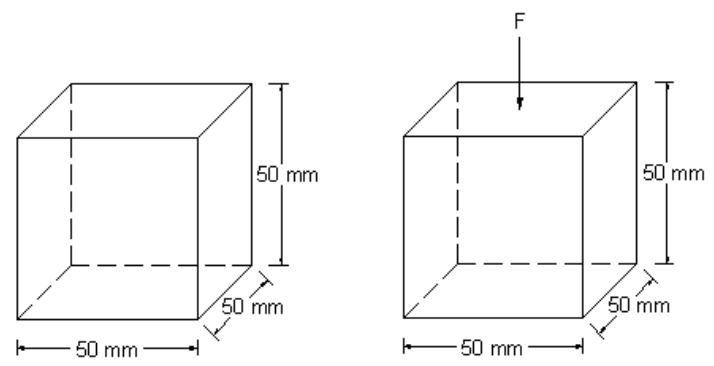

Gambar 1 Sketsa benda uji tekan

\section{B. Pengujian kuat tarik}

Benda uji untuk kuat tarik mortar maenyerupai angka delapan ukuran lebar seluruhnya $50 \mathrm{~mm}$, panjang seluruhnya $75 \mathrm{~mm}$, lebar bagian tengah $25 \mathrm{~mm}$, dan tebal $25 \mathrm{~mm}$, sketsa benda uji tarik tampak pada Gambar 2, dan rumus untuk menghitung kuat tarik adalah sebagai berikut:

$$
f_{t r}=\frac{F}{A}
$$

Dengan : $\mathrm{f}_{\mathrm{tr}}=$ kuat tarik mortar $\left(\mathrm{kg} / \mathrm{cm}^{2}\right), \mathrm{F}=$ beban tarik maksimum $(\mathrm{kg}), \mathrm{A}=$ luas bidang tarik $\left(\mathrm{cm}^{2}\right)$
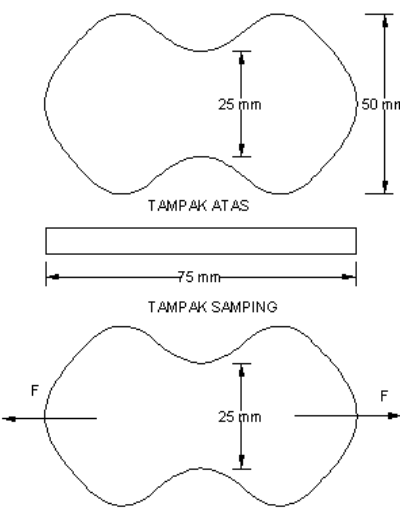

Gambar 2 Sketsa benda uji tarik

\section{Pengujian daya serap}

Batako hampir sama dengan mortar bila ditinjau dari bahan susunnya. Maka rumus untuk mencari daya serap air adalah sebagai berikut (Tjokrodimuljo, 1992 ) :

\section{Dengan :}

$$
P=\frac{W-W k}{W k} \times 100 \%
$$

$\mathrm{P}=$ Prosentasi air yang diserap ( $\%)$,

$\mathrm{W}=$ berat setalah direndam dalam air (gram),

$\mathrm{Wk}=$ berat kering oven setelah direndam (gram)

\section{Pengujian Kuat lentur}

Pengujian kuat lentur dilakukan dengan membuat benda uji berupa balok mortar dengan ukuran standar panjang $300 \mathrm{~mm}$, lebar $50 \mathrm{~mm}$ dan tinggi $50 \mathrm{~mm}$. Rumus yang digunakan adalah sebagai berikut:

$$
\mathrm{Flt}=\frac{\mathrm{M} . \mathrm{Y}}{\mathrm{I}} \longrightarrow \mathrm{M}=1 / 4 \mathrm{PL} ; \mathrm{Y}=1 / 2 \mathrm{~d} ; \mathrm{I}=1 / 12 \mathrm{~b} \mathrm{~d}^{3}
$$


$\mathrm{FIt}=\frac{1 / 4 \mathrm{P} \cdot \mathrm{L} \cdot 1 / 2 \mathrm{~d}}{1 / 12 \mathrm{bd}^{3}}=\frac{12 \mathrm{P} \cdot \mathrm{L} \cdot \mathrm{d}}{8 \mathrm{bd} \mathrm{d}^{3}} \quad$ Maka $: \mathrm{FIt}=\frac{3 \mathrm{PL}}{2 \mathrm{bd}^{2}}$

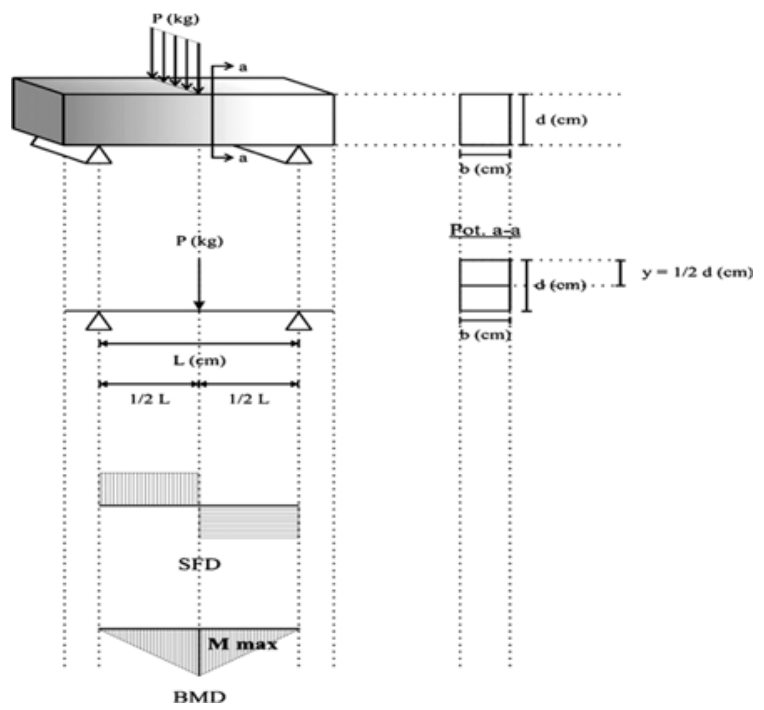

Gambar 3.Gambar uji lentur pada pembebanan balok.

Dengan :

Flt : Kuat lentur mortar $\left(\mathrm{kg} / \mathrm{cm}^{2}\right)$,

$\mathrm{P}$ : Beban maximum ( $\mathrm{kg})$,

B : Lebar benda uji $(\mathrm{cm})$,

d : Tinggi benda uji $(\mathrm{cm})$,

L : Jarak titik tumpu ( $\mathrm{cm})$.

\section{HASIL PENELITIAN DAN PEMBAHASAN}

\subsection{Tahap Pembuatan Benda Uji}

\section{A. Perhitungan kebutuhan bahan susun}

Tahap perhitungan kebutuhan bahan susun dalam penelitian ini menggunakan metode " Rode Note No. 4 ". Dalam metode ini dinyatakan bahwa kekuatan tidak mutlak ditentukan oleh banyaknya semen tetapi dipengaruhi juga oleh faktor perbandingan berat air, semen, serta kelompok butiran, dengan demikian terdapat korelasi antara nilai kekuatan mortar, kekuatan semen dan jumlah air yang dipakai.

Penggunaan bahan tambah yang berupa tras dilakukan dengan cara mencampurkannya pada adukan beton dengan perbandingan $0 \%, 10 \%, 20 \%$, dan $30 \%$ terhadap pasir. Pembuatan benda uji untuk setiap prosentase sebanyak tiga buah, untuk mengetahui kebutuhan bahan susun mengunkan rumus "Road Note No.4" ada pada persamaan 3.1.

Dari rumus diatas maka nilai $S$ diketahui yaitu 0,354 ton, jadi dapat dihitung kebutuhan untuk bahan susun beton untuk $1 \mathrm{~m} 3$ beton.

$\begin{array}{lllll}\text { Semen } & =0.354 \text { ton } & = & 354 & \mathrm{~kg} \\ \text { Air } & =0.6 \times 354 & =212 & \mathrm{~kg} \\ \text { Pasir } & =5 \times 354 & =1768 \mathrm{~kg}\end{array}$

Kontrol berat bahan susun beton total 


$$
\begin{aligned}
& =354+212+1768=2.333 \mathrm{~kg} / \mathrm{m}^{3}<2400 \mathrm{~kg} / \mathrm{m}^{3} \\
& =\text { Memenuhi syarat }
\end{aligned}
$$

\begin{tabular}{|c|c|c|c|c|c|c|c|c|}
\hline \multirow{3}{*}{$\begin{array}{l}\text { Bahan } \\
\text { susun }\end{array}$} & \multicolumn{8}{|c|}{ Kode/Prosentasi penambahan tras terhadap pasir } \\
\hline & \multicolumn{2}{|c|}{$\mathrm{MN}(0 \%)$} & \multicolumn{2}{|c|}{ MT ( $10 \%)$} & \multicolumn{2}{|c|}{ MT ( $20 \%)$} & \multicolumn{2}{|c|}{ MT $(30 \%)$} \\
\hline & M3 & $\mathrm{Kg}$ & M3 & $\mathrm{Kg}$ & M3 & $\mathrm{Kg}$ & M3 & $\mathrm{Kg}$ \\
\hline Semen & 0.112 & 354 & $2^{0.11}$ & 354 & 0.112 & 354 & 0.112 & 354 \\
\hline Air & 0.212 & 212 & $2^{0.21}$ & 212 & 0.212 & 212 & 0.212 & 212 \\
\hline Pasir & 0.662 & 1768 & $6^{0.59}$ & 1591 & 0.530 & 1414 & 0.464 & 1238 \\
\hline Tras & - & - & $6^{0.06}$ & 177 & 0.132 & 354 & 0.199 & 530 \\
\hline Jumlah & 1.000 & 2334 & $0^{1.00}$ & 2334 & 1.000 & 2334 & 1.000 & 2334 \\
\hline
\end{tabular}

Tabel : 4.Kebutuhan bahan susun mortar per m3

\subsection{Bahan Susun Mortar}

\section{A. Pengujian gradasi pasir}

Pengujian gradasi ini bertujuan untuk mengetahui distribusi ukuran agregat yaitu pasir. Dalam pengujian gradasi, lubang ayakan yang dipakai adalah $4,8 \mathrm{~mm}$, $2,4 \mathrm{~mm}, 1,2 \mathrm{~mm}, 0,6 \mathrm{~mm}, 0,3 \mathrm{~mm}$, dan $0,15 \mathrm{~mm}$, sampel pasir yang diambil lolos ayakan $4,8 \mathrm{~mm}$ dan hasil pengujian dapat dilihat pada Tabel 4.1. Modulus Halus Butir sebesar 2,89 Untuk mengetahui kekasaran dan kehalusan dapat dilihat pada tabel 4.2.Dari Gambar 4.1. dapat diketahui bahwa pasir sungai Krasak termasuk daerah II yang berarti pasirnya agak kasar.

Tabel 5 Gradasi Pasir ( Tjokrodimulya, 1996 )

\begin{tabular}{|c|c|c|c|c|}
\hline \multirow{2}{*}{$\begin{array}{c}\text { Lubang } \\
\text { ayakan(mm) }\end{array}$} & \multicolumn{4}{|c|}{ Persen butir - butir yang lewat ayakan } \\
\cline { 2 - 5 } & $\begin{array}{c}\text { Daerah I } \\
\text { (Kasar) }\end{array}$ & $\begin{array}{c}\text { Daerah II } \\
\text { (Agak Kasar) }\end{array}$ & $\begin{array}{c}\text { Daerah III } \\
\text { (Agak Halus) }\end{array}$ & $\begin{array}{c}\text { Daerah IV } \\
\text { (Halus) }\end{array}$ \\
\hline 4.8 & $90-100$ & $90-100$ & $90-100$ & $90-100$ \\
\hline 4.7 & $60-75$ & $75-100$ & $85-100$ & $95-100$ \\
\hline 1,2 & $30-70$ & $55-90$ & $75-100$ & $90-100$ \\
\hline 0.6 & $15-34$ & $35-59$ & $60-79$ & $80-100$ \\
\hline 0,3 & $2-20$ & $8-30$ & $12-40$ & $15-50$ \\
\hline 0,15 & $0-10$ & $0-10$ & $0-10$ & $0-15$ \\
\hline
\end{tabular}

Dari hasil pengujian pengujian gradasi pasir ( Tabel 4.1 ) dengan cara berat lewat kumulatif pasir dipoltkan dengan (Tabel 4.2 ), seperti tercantum pada gambar 4.1. 


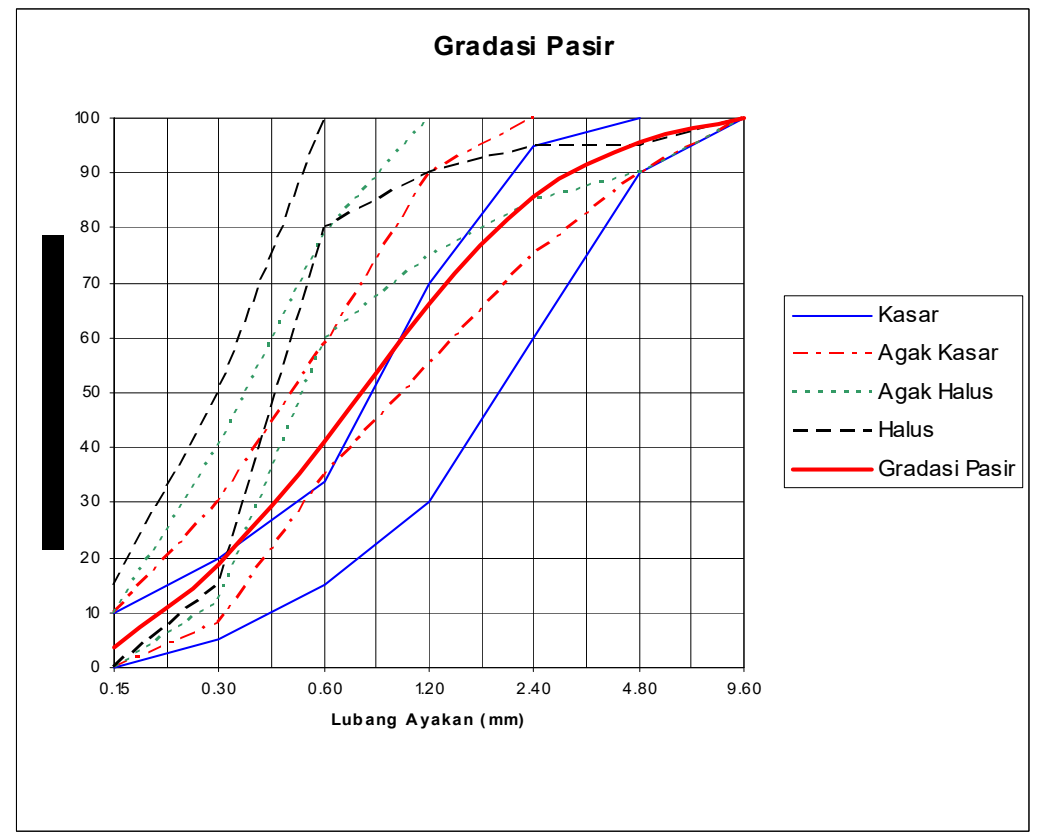

Gambar 4 Gradasi pasir hasil penelitian setelah di-plot-kan ke dalam gradasi pasir (Tjokrodimuljo,1996)

\section{B. Pengujian berat jenis agrerat}

Pengujian berat pasir bertujuan untuk mengetahui hitungan volume benda uji dan berat jenis agregat. Berat jenis agregat dapat dibagi menjadi tiga yaitu agregat ringan, agregat normal, dan agregat berat. Agregat normal adalah agregat yang berat jenisnya antara 2,5 sampai 2,7 , agregat ringan mempunyai berat jenis kurang dari 2,0, sedangkan agregat besar mempunyai berat jenis lebih dari 2,8. Hasil Pengujian didapat bahwa pasir kerasak termasuk argregat normal dapat dilihat pada tabel 6

Tabel 6 Hasil pemeriksaan berat jenis dan serapan air agregat halus

\begin{tabular}{|c|c|c|c|c|c|}
\hline \multirow{2}{*}{ No. } & \multirow{2}{*}{\multicolumn{2}{|c|}{ Pemeriksaan }} & \multirow{2}{*}{ Satuan } & \multicolumn{2}{|c|}{ Sampel } \\
\hline & & & & A & $\mathrm{B}$ \\
\hline 1 & \multicolumn{2}{|c|}{ Berat pasir kering oven (Bk) } & gram & 483 & 484.1 \\
\hline 2 & \multicolumn{2}{|c|}{ Berat benda uji kering permukaan jenuh (SSD) } & gram & 500 & 500 \\
\hline 3 & \multicolumn{2}{|c|}{ Berat piknometer diisi air $(\mathrm{B})$} & gram & 667.2 & 667.2 \\
\hline 4 & \multicolumn{2}{|c|}{ Berat piknometer + benda uji (SSD) + air (Bt) } & gram & 979.8 & 980.01 \\
\hline \multirow[t]{2}{*}{5} & $\begin{array}{l}\text { Berat Jenis Kering Oven } \\
\text { (Bulk) }\end{array}$ & $\frac{\mathrm{Bk}}{(\mathrm{B}+500-\mathrm{Bt})}$ & & 2.577 & 2.586 \\
\hline & \multicolumn{2}{|l|}{ Rata-rata } & & \multicolumn{2}{|c|}{2.582} \\
\hline \multirow[t]{2}{*}{6} & $\begin{array}{l}\text { Berat Jenis Kering } \\
\text { Permukaan Jenuh (SSD) }\end{array}$ & $\frac{500}{(\mathrm{~B}+500-\mathrm{Bt})}$ & & 2.668 & 2.671 \\
\hline & \multicolumn{2}{|l|}{ Rata-rata } & & \multicolumn{2}{|c|}{2.670} \\
\hline \multirow[t]{2}{*}{7} & $\begin{array}{l}\text { Berat Jenis Semu } \\
\text { (Appevent) }\end{array}$ & $\frac{\mathrm{Bk}}{(\mathrm{B}+\mathrm{Bk}-\mathrm{Bt})}$ & & 2.835 & 2.826 \\
\hline & \multicolumn{2}{|l|}{ Rata-rata } & & \multicolumn{2}{|c|}{2.830} \\
\hline \multirow[t]{2}{*}{8} & Penyerapan (Absorbsi) & $\frac{(500-\mathrm{Bk}) \times 100 \%}{\mathrm{Bk}}$ & & 3.520 & 3.284 \\
\hline & \multicolumn{2}{|l|}{ Rata-rata } & & \multicolumn{2}{|c|}{3.402} \\
\hline
\end{tabular}

52 Pemanfaatan Serbuk Halus Tras Asal Kulon Progo Sebagai Pengganti Sebagian Semen Pada Mortar (Nurokhman) 


\section{Pengujian kadar lumpur pasir}

Untuk kadar lumpur pada agregat halus adalah 1.55\%, hasil pemeriksaan tersebut menunjukkan, bahwa kadar lumpur yang terkandung di dalam pasir di bawah $5 \%$, berarti pasir tersebut memenuhi syarat dan dapat digunakan.dapat dilihat pada tabel 7

Tabel 67Hasil pemeriksaan kadar lumpur agregat halus

\begin{tabular}{|c|c|c|c|c|}
\hline \multirow{2}{*}{ No. } & \multirow{2}{*}{\multicolumn{2}{|c|}{ Pemeriksaan }} & \multicolumn{2}{|c|}{ Sampel } \\
\hline & & & A & $\mathrm{B}$ \\
\hline 1 & Berat tempat & w1 & 81.40 & 82.60 \\
\hline 2 & Berat pasir awal + tempat & w2 & 181.40 & 182.60 \\
\hline 3 & Berat pasir awal & $w 3=w 2-w 1$ & 100.00 & 100.00 \\
\hline 4 & Berat pasir kering + tempat & w4 & 179.80 & 181.10 \\
\hline 5 & Berat pasir kering & $w 5=w 4-w 1$ & 98.40 & 98.50 \\
\hline 6 & Kandungan Lumpur & $\frac{w 3-w 5}{w 3} \times 100 \%$ & 1.60 & 1.50 \\
\hline 7 & Rata-rata kandungan lumpur & $\%$ & & \\
\hline
\end{tabular}

\section{Pengujian gradasi tras}

Pengujian gradasi ini bertujuan untuk mengetahui distribusi ukuran agregat pada tras, hasil pengujian tampak pada Tabel 8

Tabel 8 Gradasi Tras Kulonprogo

\begin{tabular}{|c|c|c|c|c|c|c|}
\hline \multirow[t]{2}{*}{ NO } & \multicolumn{2}{|c|}{$\begin{array}{l}\text { Ukuran } \\
\text { Saringan }\end{array}$} & \multirow{2}{*}{$\begin{array}{c}\text { Berat } \\
\text { masing }{ }^{2} \\
\text { Tertinggal } \\
\text { (gr) }\end{array}$} & \multirow{2}{*}{$\begin{array}{c}\text { Berat } \\
\text { Jumlah } \\
\text { tertinggal } \\
\quad(\mathrm{gr})\end{array}$} & \multirow{2}{*}{$\begin{array}{c}\text { Jumlah } \\
\text { Tertinggal } \\
(\%)\end{array}$} & \multirow{2}{*}{$\begin{array}{c}\text { Jumlah } \\
\text { Melalui } \\
(\%)\end{array}$} \\
\hline & No & $\mathrm{mm}$ & & & & \\
\hline 1 & 4 & 4.760 & 0 & 0 & 0.00 & 100.00 \\
\hline 2 & 8 & 2.380 & 0 & 0 & 0.00 & 100.00 \\
\hline 3 & 16 & 1.490 & 393.7 & 393.7 & 39.37 & 60.63 \\
\hline 4 & 30 & 0.600 & 252.1 & 645.7 & 64.57 & 35.43 \\
\hline 5 & 50 & 0.300 & 139.7 & 785.5 & 78.55 & 21.45 \\
\hline 6 & 100 & 0.149 & 103.3 & 888.7 & 88.87 & 11.13 \\
\hline 7 & 200 & 0.074 & 62.0 & 950.7 & 95.07 & 4.93 \\
\hline 8 & Panci & & 49.3 & 1000 & 100.00 & \\
\hline \multicolumn{3}{|c|}{$\mathrm{Jumlah}$} & 1000 & & 271.36 & \\
\hline
\end{tabular}




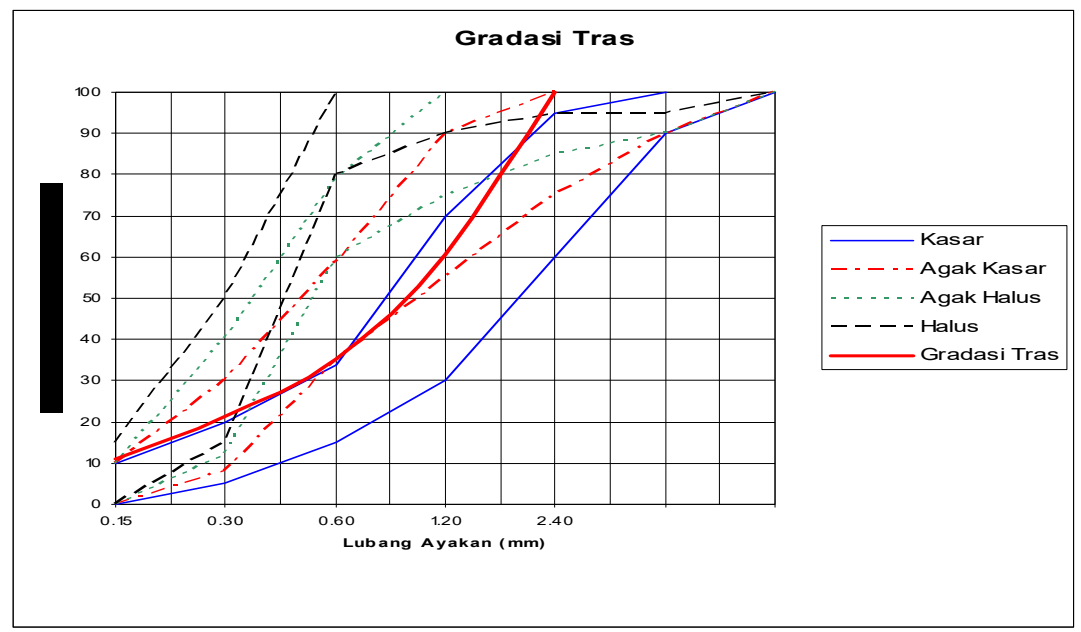

Gambar 5 Gradasi tras hasil penelitian setelah di-plot-kan ke dalam gradasi pasir (Tjokrodimuljo,1996).

\section{E. Pengujian unsur kimia}

Pengujian ini bertujuan untuk mengetahui kadar zat-zat kimia yang terkandung dalam tras, setelah dilakukan pengujuan, kadar silika yang paling besar $\mathrm{S}_{\mathrm{i}} \mathrm{O}_{2}=64.2150 \%, \mathrm{Al}_{2} \mathrm{O}_{3}=27.1244 \%$ dan $\mathrm{Fe}_{2} \mathrm{O}_{3 \%}=5.7203 \%$ dari 3 unsur tersebut bila dijumlah telah memenuhi syarat (Portland Pozzolan Cement (PPC),1994) .

\section{F. Uji Meja Sebar}

Didalam campuran beton/mortar perlu diketahui kosistensi (kelecekannya) maka untuk itu di dalam mengetahui kelecekannya dilakukan pengujian meja sebar (uji leleh) sebelum adukan dihitung dalam cetakan.. Hasil uji sebar tampak pada Tabel 9

Tabel 9 Hasil uji sebar dari masing-masing campuran

\begin{tabular}{|c|c|c|c|c|c|c|}
\hline No & Kode & \multicolumn{4}{|c|}{ Panjang (\%) } & Panjang total (\%) \\
\hline 1 & MN & 40 & 40 & 35 & 35 & 150 \\
\hline 2 & $\mathrm{MT}_{10}$ & 40 & 40 & 45 & 45 & 170 \\
\hline 3 & $\mathrm{MT}_{20}$ & 40 & 40 & 45 & 45 & 170 \\
\hline 4 & $\mathrm{MT}_{30}$ & 35 & 35 & 40 & 40 & 150 \\
\hline
\end{tabular}

\subsection{Pengujian Sifat Mekanik Beton Normal}

\section{A. Berat Volume}

Berat volume beton sangat tergantung pada berat jenis dan gradasi agregat yang dipakai (Kardiyono Tjokrodimulyo, 1996). Dari tabel pemeriksaan menunjukkan bahwa penambahan tras mempengaruhi penurunan berat volume. Semakin banyak penambahan tras maka volumenya semakin menurun. Seperti terlihat dalam tabel berikut ini :

Tabel 10 Berat volume mortar

\begin{tabular}{|l|c|c|c|}
\hline \multirow{2}{*}{ Type } & \multicolumn{3}{|c|}{ Berat volume rata-rata } \\
\cline { 2 - 4 } & 14 & 21 & 28 \\
\hline MN & 2084 & 2026 & 2025 \\
\hline MT 10\% & 1932 & 1944 & 1969 \\
\hline MT 20\% & 1939 & 1907 & 1934 \\
\hline MT 30\% & 1901 & 1930 & 1865 \\
\hline
\end{tabular}

54 Pemanfaatan Serbuk Halus Tras Asal Kulon Progo Sebagai Pengganti Sebagian Semen Pada Mortar (Nurokhman) 


\section{B. Pengujian Kuat Tekan Mortar}

Pengujian kuat tekan mortar dilakukan pada mortar yang berbentuk kubus dengan dimensi $50 \mathrm{~mm} \times 50 \mathrm{~mm} \times 50 \mathrm{~mm}$ pada umur 14, 21 dan 28 hari. Dari hasil pengujian, dengan jumlah penambahan tras sebesar 10\%, 20\%, 30\% terhadap mortar normal menunjukkan penurunan kuat tekannya. Dari hasil penhitungan bahwa untuk mortar normal bisa di konversikan tapi untuk mortar dengan bahan tambah tras tidak bisa dikonversi bedasrkan teori (PB,1989:16). hasilnya dapat dilihat pada Gambar.6

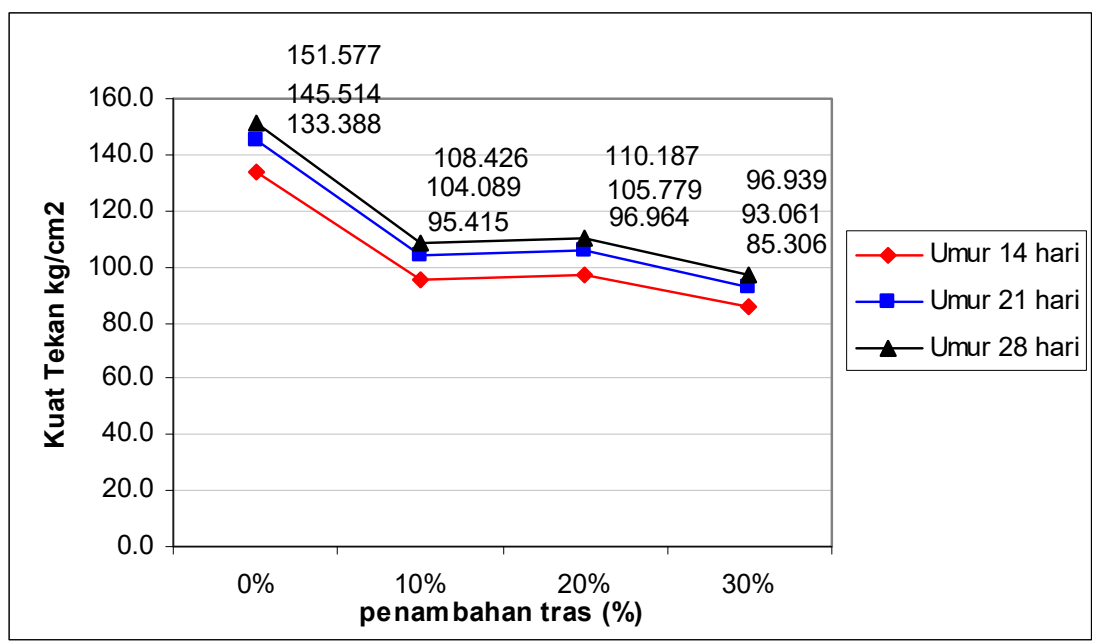

Gambar 6 pertumbuhan kuat tekan mortar setelah dikonvarsi

\section{Pengujian Kuat Lentur Mortar}

Pengujian kuat lentur dilakukan setelah mortar dengan ukuran 50 × 50 × 300 $\mathrm{mm}$ berumur 28 hari. Dari semua sampel benda uji yang diuji kuat lenturnya, diperoleh hasil bahwa mortar dengan bahan tambah tras semuanya menunjukan penurunan pada kuat lentur mortar normal. Untuk hasil pengujian kuat lentur beton dapat dilihat pada gambar 7

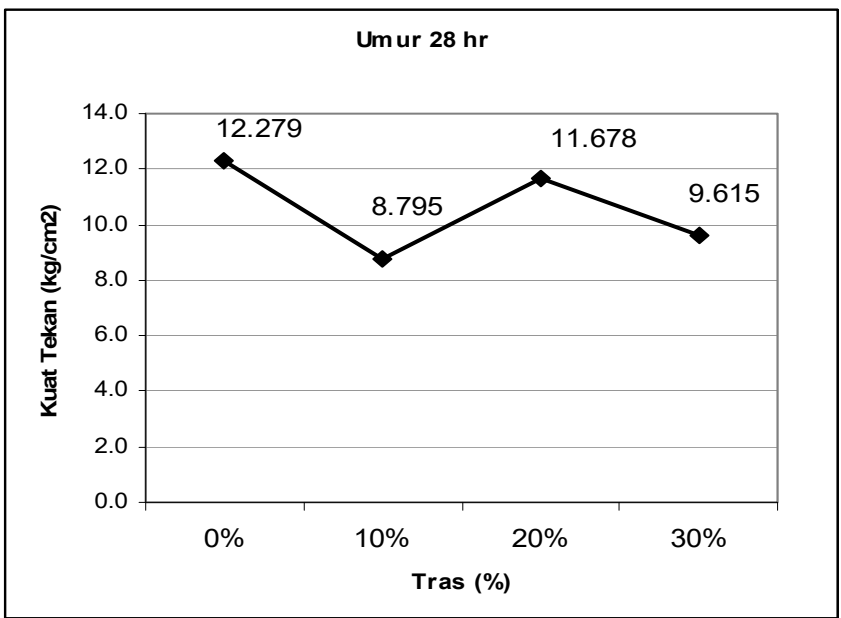

Gambar 7 Grafik kuat lentur mortar pada umur 28 hari

\section{Pengujian Kuat Tarik Mortar}


Pengujian kuat lentur dilakukan setelah mortar dengan berumur 28 hari. Dari semua sampel benda uji yang diuji kuat tarik, diperoleh hasil bahwa mortar dengan bahan tambah tras semuanya menunjukan penurunan pada kuat trik mortar normal. Untuk hasil pengujian kuat lentur beton dapat dilihat pada gambar 8

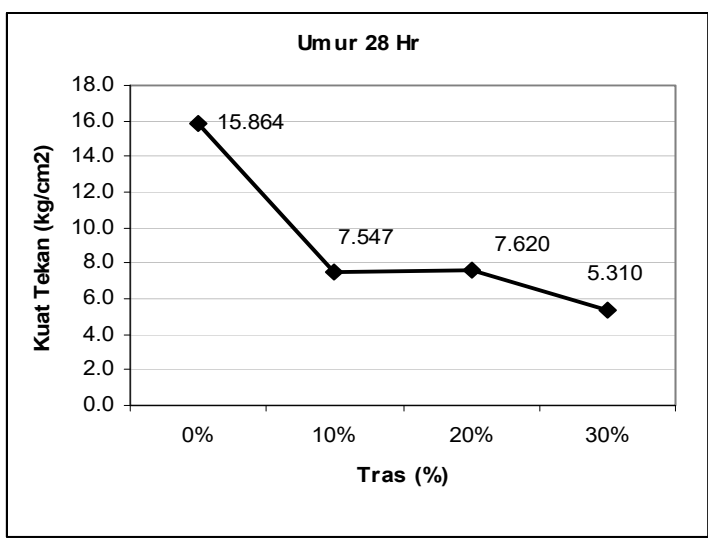

Gambar 8 Grafik kuat tarik mortar pada umur 28 hari

\section{E. Pengujian Daya Serap Air}

Hasil pengujian mortar dengan bahan tambah tras diperoleh nilai serapan air pada masing-maising prosentasi mulai dari 0\% sampai 30\% tampak bahwa dengan adanya penambahan tras maka nilai serapan air meningkat $8.11 \%$ sampai $13.85 \%$, dengan penambahan tras ternyata dapat meningkatkan daya serap air terhadap mortar, bearti tras dapat menyerap air pada mortar seperti terlihat dalam tebel dibawah ini:

Tabel 11 Hasil pengujian daya serap air

\begin{tabular}{|c|c|c|c|c|c|}
\hline Kode & Sempel & $\begin{array}{c}\text { W1 } \\
\text { (gram) }\end{array}$ & $\begin{array}{l}\text { W2 } \\
\text { (gram) }\end{array}$ & $k a m=\frac{w 1-w 2}{w 2} \times 100 \%$ & $\begin{array}{c}\text { Rata-rata } \\
(\%)\end{array}$ \\
\hline \multirow{2}{*}{$\mathrm{MN}$} & 1 & 267.60 & 247.90 & 7.947 & \multirow{2}{*}{8.11} \\
\hline & 2 & 282.60 & 261.00 & 8.276 & \\
\hline \multirow{2}{*}{$\begin{array}{l}\text { MT } \\
10 \%\end{array}$} & 1 & 255.80 & 222.20 & 15.122 & \multirow{2}{*}{13.85} \\
\hline & 2 & 256.10 & 227.50 & 12.571 & \\
\hline \multirow{2}{*}{$\begin{array}{c}\text { MT } \\
20 \%\end{array}$} & 1 & 264.10 & 237.10 & 11.388 & \multirow{2}{*}{11.03} \\
\hline & 2 & 260.40 & 235.30 & 10.667 & \\
\hline \multirow{2}{*}{$\begin{array}{c}\text { MT } \\
30 \%\end{array}$} & 1 & 266.40 & 226.60 & 17.564 & \multirow{2}{*}{12.59} \\
\hline & 2 & 254.60 & 236.60 & 7.608 & \\
\hline
\end{tabular}

\subsection{Hubungan Sifat Mekanis Beton Tras dengan Sifat-sifat lainya}

Dari hasil pengujian kuat tekan mortar pada mortar umur 28 dikonversikan berdasarkan teori (PB,1989:16). Dari hasil penhitungan bahwa untuk mortar normal bisa di konversikan tapi untuk mortar dengan bahan tambah tras tidak bisa dikonversi bedasrkan teori (PB,1989:16). hasilnya dapat dilihat pada Gambar.5 dan Gambar 4 : Berdasarkan pada gambar grafik perbandingan kuat tekan mortar dapat disimpulkan bahwa kekuatan mortar dari masing-masing variasi prosen penambahan tras mengalami kenaikan ketika umur mortar bertambah ini disebabkan selama proses perendaman berlangsung udara yang ada pada mortar tidak terperangkap oleh pori-pori mortar sehingga ikatan antar bahan susun makin baik dan kuat serta tidak terpengaruh oleh suhu udara berlangsung sudah terjadi ikatan antar bahan susun dengan baik dan tidak terjadi retak-retak pada mortar.

56 Pemanfaatan Serbuk Halus Tras Asal Kulon Progo Sebagai Pengganti Sebagian Semen Pada Mortar (Nurokhman) 


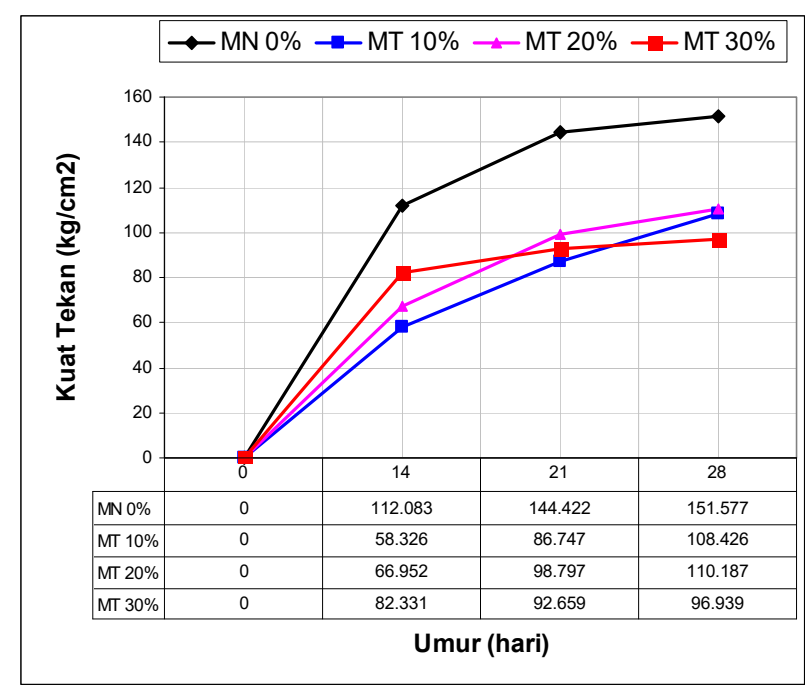

Gambar 9 Grafik hubungan antara kuat tekan dan umur (hari)

Dari hasil pengujian kuat tekan bila diplotkan dengan persyaratan batako menurut PUBI 1982 maka kuat tekan mortar dengan bahan susun penambahan tras untuk batako masuk dalam persyaratan tersebut.

Dari hasil pengujian kuat tekan dari Gambar.8 Gambar 6 dibuat grafik hubungan kuat tekan mortar dengan prosentase penambahan tras, yaitu grafik tersebut dapat dilihat pada Gambar 9

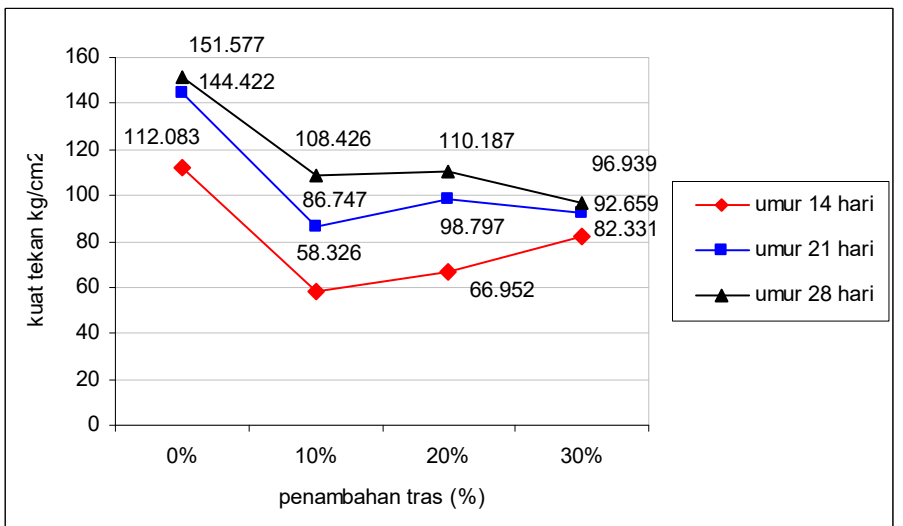

Gambar 10 Hubungan kuat tekan mortar dengan prosentase penambahan tras

Beradasarkan gambar hubungan kuat tekan dan prosentase penambahan tras di atas dapat disimpulkan, bahwa ketika trasnya bertambah maka kuat tekannya turun. Dengan demikian penggantian pasir dengan tras tidak sebaik dengan pasirnya. Walaupun tras merupakan salah satu bahan baku pembuat semen.

Beradasarkan Gambar 7 kuat lentur dan prosentase penambahan tras di atas dapat disimpulkan, bahwa ketika trasnya bertambah maka kekuatannya turun. Penambahan tras $20 \%$ terjadi kenaikan pada penambahna $10 \%$ dan $30 \%$ tapi jika dibandingkan dengan penambahan $0 \%$ terjadi penurunan. Dengan demikian penggantian pasir dengan tras tidak sebaik dengan pasirnya. Walaupun tras merupakan salah satu bahan baku pembuat semen.

Dari hasil pengujian kuat tarik dari Gambar 6 dibuat grafik hubungan kuat lentur mortar dengan prosentase penambahan tras. Beradasarkan analisis 
hubungan kuat tarik dan prosentase penambahan tras di atas dapat disimpulkan, bahwa ketika trasnya bertambah maka kekuatannya turun. Dengan demikian penggantian pasir dengan tras tidak sebaik dengan pasirnya. Walaupun tras merupakan salah satu bahan baku pembuat semen.

Dari hasil pengujian kuat lentur dari Gambar 7 dibuat grafik hubungan kuat lentur mortar dengan prosentase penambahan tras. Berdasarkan analisis hubungan daya serap air dan prosentase penambahan tras di atas dapat disimpulkan, bahwa dengan bertambahnya tras maka daya serap air menjadi naik ini di sebabkan karena tras memiliki daya serap air cukup besar.

Dari hasil pengujian kuat tekan dan pengujian daya serap air dapat dibuat grafik hubungan antara kuat tekan dengan daya serap air.

Berdasarkan tabel hasil pengujian kuat tekan dan grafik hubungan kuat tekan dengan daya serap air di atas dapat diambil suatu pengertian bahwa penambahan tras berpengaruh terhadap kuat tekan dan daya serap air, dimana dengan penambahan tras kuat tekannya mengalami penurunan tapi menaikan daya serap air.

Dari hasil pengujian kuat lentur dan pengujian daya serap air, dapat dibuat grafik hubungan antara kuat lentur dengan daya serap air.

Berdasarkan analsis hasil pengujian kuat lentur dan grafik hubungan kuat tekan dengan daya serap air di atas dapat diambil suatu pengertian bahwa penambahan tras berpengaruh terhadap kuat lentur. Semakin besar resapan air maka semakin menurun kuat lenturnya, tampak pada resapan air $13.850 \%$ dan kuat lenturnya $8.795 \mathrm{~kg} / \mathrm{cm}^{2}$

Berdasarkan tabel hasil pengujian kuat tarik dan grafik hubungan kuat tarik dengan daya serap air di atas dapat diambil suatu pengertian bahwa penambahan tras berpengaruh terhadap kuat tarik. Pada serapan air $13.850 \%$ kuat tariknya 7.547 $\mathrm{kg} / \mathrm{cm}^{2}$, serapan air $11.030 \%$ kuat tariknya $7.620 \mathrm{~kg} / \mathrm{cm}^{2}$ dan serapan air $12.590 \%$ kuat tarik $5.310 \mathrm{~kg} / \mathrm{cm}^{2}$ jadi Semakin banyak serapan air makin menurun kuat tariknya. Walaupun serasapan air $13.850 \%$ lebih baik dari $12.590 \%$ tapi jika dibandingkan mortar normal jauh lebih bagus dari mortar normal yaitu serapan air $8.11 \%$ dan kuat tariknya $15.864 \mathrm{~kg} / \mathrm{cm}^{2}$.

\section{KESIMPULAN}

Dari hasil penelitian yang telah dilakukan dapat diambil kesimpulan sebagai berikut :

1. Agregat halus berupa pasir yang berasal dari Kali Kerasak Merapi, mempunyai berat jenis $2.670 \mathrm{gr} / \mathrm{cm}^{3}$, serta MHB 2.89 dan kadar lumpur $1.55 \%$ yang semuanya memenuhi syarat sebagai bahan susun. Dan tras mempunyai berat jenis $1.922 \mathrm{gr} / \mathrm{cm}^{3}$, kadar kimia dalam tras yang paling besar SiO2 $=64.2150 \%$.

2. Dengan penambahan tras pengganti pasir pada mortar berpengaruh pada kuat tekan yang berakibat mengalami penurunan kuat tekan sebagai berikut : kuat tekan umur 28 hari $\mathrm{MT}_{10}=28.47 \% \mathrm{MT}_{20}=27.47 \% \quad \mathrm{MT}_{30}=36.05 \%$ terhadap mortar normal

3. Dengan penambahan tras pengganti pasir pada mortar berpengaruh pada kuat lentur yang berakibat mengalami penurunan kuat kuat lentur sebagai berikut: kuat lentur umur 28 hari $\mathrm{MT}_{10}=28.37 \% \mathrm{MT}_{20}=4,897 \% \mathrm{MT}_{30}=21.69 \%$ terhadap mortar normal

4. Dengan penambahan tras pengganti pasir pada mortar berpengaruh pada kuat tarik yang berakibat mengalami penurunan kuat kuat lentur sebagai berikut: kuat tarik umur 28 hari $\mathrm{MT}_{10}=52.42 \% \mathrm{MT}_{20}=51.96 \% \quad \mathrm{MT}_{30}=66.53 \%$ terhadap mortar normal

5. Dengan penambahan tras pengganti pasir pada mortar berpengaruh pada daya serap air, mengalami kenaikan $\mathrm{MT}_{10}=5.74 \% \mathrm{MT}_{20}=2.92 \% \quad \mathrm{MT}_{30}=3.92 \%$

58 Pemanfaatan Serbuk Halus Tras Asal Kulon Progo Sebagai Pengganti Sebagian Semen Pada Mortar (Nurokhman) 
terhadap mortar normal

6. Dari hasil penelitian secara umum dengan penambahan tras terhadap pasir memenuhi syarat kuat tekan untuk batako miskipun dalam pengujian semuanya menunjukkan penurunan pada kuat tekan.

\section{DAFTAR PUSTAKA}

Dipohusodho, I, 1999, Struktur Beton Bertulang Berdasarkan SK SNI T-15-1991-03, PT Gramedia Pustaka Utama, Jakarta.

Gonita, 1998, Pengaruh Penggunaan Kapur Padam dan Kapur Mobern Pada Kuatan Mortar Semen, TA, JTS FT UGM, Yogyakarta.

Sagel, Kole, Gedeon Kusuma,1994, Pedoman Pengerjaan Beton Berdasarkan SK SNI T15-1991-03 (Seri Beton 2), Penerbit Erlangga, Jakarta.

Johanes Bangun, 1994, Geologi Daerah Wonokarto dan Sekitarnya Kab. Wonogiri dan Prospeksi Batu Gamping untuk bahan Baku Semen Portland, TA, JTG STTNas, Yogyakarta.

Lembaga Penyelidikan Masalah Bangunan, 1979, Peraturan Tras Dan Semen Merah Indonesia NI-20, Dirjen Cipta Karya, Dep. PU, Bandung.

Murdock L. J., dan Brook, K.M (diterjemahkan oleh Ir. Stephanus Hendrako), 1986, Bahan dan Praktek Beton, Edisi ke-4, Penerbit Erlagga, Jakarta.

Pusat Penelitian dan Pengembangan Pemukiman, 1992, Persyaratan Umum Bahan Bangunan Indonesia (PUBI-1982), P.U., Bandung.

Sutriman dan Nurokhman , 2001, Pengaruh Penggunaan Pasir Pantai Parangtritis Yogyakarta Terhadap Kuat Tekan dan Daya Serap Air Conblock, laporan Penelitian, JTS FT UCY, Yogyakarta.

Suyudi dan Nurokhman, 2005, Pengaruh Prnggunaan tras Untuk Mortar Semen Pada Counblok, Laporan Penelitian , FT UCY, Yogyakarta.

Tjokrodimulyo, K., 1996, Bahan Bangunan, Buku Ajar, Jurusan Teknik Sipil, Fakultas Teknik, Universitas Gajah Mada Yogyakarta. 